\title{
ICT W EDUKACJI, PROFILAKTYCE I TERAPII - PRZYKŁADY DOBRYCH PRAKTYK
}

\begin{abstract}
Borzucka-Sitkiewicz Katarzyna, Leksy Karina, ICT w edukacji, profilaktyce i terapii - przykłady dobrych praktyk [ICT in Education, Prevention and Therapy - Examples of Good Practices]. Studia Edukacyjne nr 48, 2018, Poznań 2018, pp. 187-200. Adam Mickiewicz University Press. ISSN 1233-6688. DOI: $10.14746 /$ se.2018.48.12
\end{abstract}

The dynamically developing global IT infrastructure and the increasing importance of modern information technologies represent a huge challenge in the process of socialization and education of children and young people. Undoubtedly, it is extremely important to prepare current and future generations for a skillful use of modern technologies. Therefore, it is essential to implement new technologies in the teaching process at all levels of education as well as during preventive and therapeutic activities.

This study analyzes the functioning of three institutions that use modern information technology within educational, preventive and therapeutic interventions. These institutions have been selected to be environmentally diverse, show the international context and demonstrate a different potential for ICT use. The main objective of the research was to identify innovative ways of using modern technologies in supporting educational and compensatory activities undertaken by selected institutions.

Key words: modern information technologies, education, prevention, therapy

\section{Wprowadzenie}

Nie ulega wątpliwości, że intensywny rozwój technologii informatycznej w ogromnym stopniu wpływa na współczesne zmiany cywilizacyjne i kształt rzeczywistości społeczno-kulturowej. W zasadzie trudno obecnie odnaleźć dziedzinę życia, w której technologia ta nie byłaby użytkowana, a wręcz niezbędna. Technologie informacyjne (TI) są definiowane jako „wszelkie zagadnienia, środki i metody związane z gromadzeniem, przetwarzaniem, 
przechowywaniem, przesyłaniem czy prezentowaniem informacji”1. Środki i narzędzia technologii informacyjnych stanowią warunek korzystania z dostępnych form przekazu informacji, którymi są tak zwane nowe media ${ }^{2}$. Lev Manovich określa nowe media jako

media analogowe skonwertowane do postaci cyfrowej. Ich zasadniczą cechą jest to, iż pozwalają na swobodny dostęp do danych, a ich kopiowanie nie powoduje utraty ich jakości (...), są interaktywne, co oznacza, że użytkownik może wchodzić w interakcję z obiektem medialnym ${ }^{3}$.

Współcześnie bardzo często wskazuje się na zagrożenia związane z korzystaniem z nowych mediów, szczególnie w odniesieniu do zdrowia oraz funkcjonowania dzieci i młodzieży. Wydaje się wręcz, że lista potencjalnych zagrożeń związanych z nadmiernym, bezrefleksyjnym czy nieumiejętnym użytkowaniem technologii informatycznej jest dziś dłuższa, aniżeli korzyści, jakie niewątpliwie się z nią wiążą. Oczywiście, najczęściej konsekwencje wykorzystywania nowej technologii zależą od intencji samego użytkownika. Nie ulega jednak wątpliwości, że obecnie funkcjonowanie bez nowoczesnych rozwiązań technologicznych, w tym przede wszystkim sieci internetowej, jest bardzo trudne lub wręcz niemożliwe. Zastosowanie nowych mediów jest obserwowalne w każdej dziedzinie życia, zatem nabywanie wiedzy, umiejętności i kompetencji w zakresie prawidłowego z nich korzystania jest dziś imperatywem, zarówno w kontekście edukacji dzieci i młodzieży, jak też osób dorosłych.

Dynamicznie rozwijająca się globalna infrastruktura informatyczna i wzrost znaczenia nowoczesnych technologii informacyjnych stanowią ogromne wyzwanie $\mathrm{w}$ procesie socjalizacji, wychowania oraz edukacji dzieci i młodzieży. Bez wątpienia, na tym tle niezwykle ważne jest $\mathrm{z}$ jednej strony, przygotowanie obecnego i przyszłych pokoleń do umiejętnego posługiwania się zdobyczami nauki i techniki, z drugiej natomiast wykorzystanie nowych technologii $\mathrm{w}$ procesie dydaktycznym na wszystkich szczeblach edukacji ${ }^{4}$, jak również podczas działań profilaktyczno-terapeutycznych. Warto zauważyć, że technologie informatyczne wspierają wymienione działania $\mathrm{w}$ różnorodny sposób. Przede wszystkim dostępne materiały

${ }^{1}$ M. Kłak, Zarządzanie wiedza we wspótczesnym przedsiębiorstwie, Kielce 2010. Podano za: M. Cylkowska-Nowak, E. Wierzejewska, Technologie informacyjne w edukacji zdrowotnej, [w:] Edukacja zdrowotna. Podstawy teoretyczne. Metodyka. Praktyka, red. B. Woynarowska, Warszawa 2017, s. 199.

${ }^{2}$ M. Cylkowska-Nowak, E. Wierzejewska, Technologie informacyjne, s. 200.

${ }^{3}$ L. Manovich, Język nowych mediów, Warszawa 2006, s. 119-120.

${ }^{4}$ K. Szczeszek, Technologie informacyjne a edukacja, [w:] Oblicza Internetu, red. M. Sokołowski, Elbląg 2004, s. 201. 
i programy o charakterze dydaktycznym, profilaktycznym, rewalidacyjnym mogą wspierać tradycyjne formy oddziaływania wychowawczego, a nawet przynosić lepsze efekty podejmowanych działań, gdyż technologia cyfrowa jest dla młodego pokolenia wyjątkowo atrakcyjna nie tylko w edukacji, ale także w życiu codziennym ${ }^{5}$.

Jednym z najważniejszych zastosowań technologii informatycznej jest jej wykorzystanie do szeregu działań psychopedagogicznych oraz edukacyjnych, które razem mają służyć optymalizacji rozwoju człowieka ${ }^{6}$. Kluczowe znaczenie miała tu Deklaracja w Sprawie Technologii Informacyjnych i Komunikacyjnych (ICT) na Rzecz Integracji Społeczeństwa Informacyjnego, podpisana przez ministrów państw europejskich w Rydze 11-13.06.2006 roku', która zakłada przede wszystkim

stworzenie integracyjnego społeczeństwa informacyjnego, to znaczy społeczeństwa informacyjnego dla wszystkich. Jej celem jest umożliwienie każdej zainteresowanej osobie pełnego udziału w społeczeństwie informacyjnym, niezależnie od jej ewentualnego upośledzenia społecznego czy indywidualnego ${ }^{8}$.

Program ten jest zgodny z ideą edukacji ustawicznej oraz innymi formami edukacji formalnej i nieformalnej, które są podejmowane zarówno przez instytucje edukacyjne i kulturalne, jak również instytucje zajmujące się osobami niepełnosprawnymi, społecznie wykluczonymi, czy osobami w wieku senioralnym 9 .

Warto zwrócić uwagę, że w Polsce były i są podejmowane działania mające na celu rozwój społeczeństwa informacyjnego. Wśród dokumentów, które wskazywały na aktualny stan informatyzacji kraju, jak i wyznaczających cele podejmowanych działań były między innymi: opracowany w roku 2004 przez Ministerstwo Nauki i Cyfryzacji dokument zatytułowany „Proponowane kierunki rozwoju społeczeństwa informacyjnego w Polsce do $2020 \mathrm{r}^{10 ”}$ czy "Strategia rozwoju społeczeństwa informacyjnego w Polsce

${ }^{5}$ A. Rygałło, Czy szkoła może być cyfrowa? [w:] Człowiek, technologia, media: konteksty kulturowe i psychologiczne, red. A. Ogonowska, G. Ptaszek, Kraków 2014, s. 31.

6 A. Ogonowska, Wspótczesna edukacja medialna: teoria i rzeczywistość, Kraków 2013, s. 40.

7 http://ec.europa.eu/information_society/events/ict_riga_2006/doc_declaration_ riga.pdf. [dostęp: 28.02.2012]. Podano za: tamże.

${ }^{8}$ Komunikat Komisji do Parlamentu Europejskiego, Rady, Europejskiego Komitetu Ekonomiczno-Społecznego i Komitetu Regionów, Europejska inicjatywa i2010 na rzecz e-integracji: „Uczestnictwo w społeczeństwie informacyjnym” [SEK (2007) 1469] [SEK (2007) 1470], Bruksela 8.11.2007, KOM (2007) 694, s. 2. Podano za: tamże.

${ }^{9}$ A. Ogonowska, Wspótczesna edukacja medialna, s. 41.

${ }^{10}$ http://www.nauka.gov.pl/g2/oryginal/2013_05/5de4e12caa5c43f9e7ad159505c26e03. pdf [dostęp: 12.07.2017]. 
do roku 2013 ${ }^{11 \prime \prime}$, przyjęta w roku 2008. Obydwa dokumenty zwracają między innymi uwagę na wykorzystanie nowej technologii w procesie edukacji, poprzez „podniesienie poziomu i dostępności edukacji (od przedszkola do uczelni wyższej) oraz upowszechnienie zasady nauki przez całe życie poprzez wykorzystanie technologii informacyjnych i komunikacyjnych" (Obszar Człowiek - Cel 2 „Strategii rozwoju (...)"). Jednocześnie ważne jest, że brane pod uwagę są także takie kwestie, jak: integracja społeczna, aktywizacja społeczna, minimalizowanie zakresu i ewentualnych skutków cyfrowego wykluczenia $^{12}$. Aktualnie jednym z projektów realizowanych przez Ministerstwo Cyfryzacji, który zakłada stworzenie sieci dostępu do Internetu łączącej wszystkie szkoły w Polsce (ok. 30,5 tys.) jest „Ogólnopolska Sieć Edukacyjna"13. W swoich założeniach OSE ma być siecią wirtualną opartą na istniejącej infrastrukturze szerokopasmowej i dostarczać szkołom usług dostępu do Internetu (o przepustowości co najmniej $100 \mathrm{Mb}$ / s wraz z usługami bezpieczeństwa) oraz treści edukacyjnych i wsparcia w procesie kształcenia umiejętności cyfrowych. Projekt ten zakłada, że jego realizacja pozwoli na:

1) cywilizacyjną zmianę w sposobie kształcenia uczniów poprzez przejście z edukacji analogowej (książki) na edukację cyfrową (korzystanie z treści udostępnionych w Internecie),

2) wprowadzenie nowych form kształcenia oraz nowych programów nauczania kompetencji i umiejętności cyfrowych (np. powszechna nauka programowania),

3) wyrównanie szans edukacyjnych wszystkich uczniów w Polsce, w szczególności uczniów zamieszkujących tereny o niskiej gęstości zaludnienia i uczących się w szkołach o małej liczbie uczniów, dla których dostęp do nowoczesnych źródeł i strumieni wiedzy jest krytycznym elementem podnoszenia ich potencjału,

4) transfer wiedzy i doświadczeń pomiędzy jednostkami edukacyjnymi z wykorzystaniem nowoczesnych technologii ${ }^{14}$.

Nowoczesne technologie informatyczne są obecnie szeroko wykorzystywane $\mathrm{w}$ procesie edukacji oraz w profilaktyce i terapii zarówno w Polsce, jak i na świecie. Oczywiście zasięg, sposób i różnorodność stosowanych oddziaływań są różne i w znacznym stopniu zależą od potrzeb danej zbiorowości, możliwości finansowych i ogólnej dostępności do konkretnych rozwiązań technologicznych.

${ }^{11}$ http://www.umwd.dolnyslask.pl/fileadmin/user_upload/spoleczenstwo_informacyjne/dokumenty/Strategia_Rozwoju_Spoleczenstwa_Informacyjnego_w_Polsce.pdf [dostęp: 12.07.2017].

12 A. Ogonowska, Wspótczesna edukacja medialna, s. 41.

${ }^{13}$ https:// mc.gov.pl/projekty/ogolnopolska-siec-edukacyjna [dostęp: 12.07.2017].

${ }^{14}$ https://mc.gov.pl/projekty/ogolnopolska-siec-edukacyjna/opis-projektu [dostęp: 12.07.2017]. 


\section{Metoda i teren badań własnych}

W niniejszym opracowaniu wzięto pod uwagę trzy instytucje, w których stosowana jest nowoczesna technologia informatyczna $\mathrm{w}$ ramach oddziaływań edukacyjnych, profilaktycznych i terapeutycznych. Instytucje te zostały tak dobrane, aby były zróżnicowane środowiskowo, ukazywały kontekst międzynarodowy i przedstawiały różne możliwości wykorzystywania technologii ICT. Były to:

- Classical High School z klasami sportowymi w Kuopio (Finlandia) - jest to szkoła dla uczniów z normą intelektualną oraz dla młodzieży uzdolnionej fizycznie/ruchowo w wieku od 16 do 19 lat. Obecnie do szkoły tej uczęszcza ponad 630 uczniów, w tym 200 sportowców. Placówka zatrudnia 38 nauczycieli, w tym 15 trenerów. Uczniowie mają tu dostęp do najnowszej technologii informatycznej m.in. komputerów, drukarki 3D i wirtualnych słuchawek ${ }^{15}$.

- Szkoła podstawowa nr 3 w Bytomiu (Polska) - placówka zlokalizowana jest w centrum miasta. W roku szkolnym 2016/2017 uczęszczało do niej 400 uczniów, co stanowiło 20 klas, w tym 5 klas terapeutycznych. Lokalizacja szkoły w znacznym stopniu wpływa na rodzaj problemów pojawiających się w funkcjonowaniu uczniów, jak i ich rodzin. Wielu uczniów ma deficyty rozwojowe, co niejednokrotnie wiąże się ze specyfiką środowiska wychowawczego - 19\% uczniów wychowuje się w rodzinach o niskim statusie materialnym, $26 \% \mathrm{w}$ rodzinach o niepełnej strukturze, $26 \%$ pochodzi z rodzin wielodzietnych, co przy złych warunkach ekonomicznych oddziałuje niekorzystnie na ich osiągnięcia szkolne. W zakresie funkcjonowania biopsychospołecznego uczniów: 31\% wykazuje trudności w zakresie czytania, 36\% w zakresie pisania, 33\% w zakresie liczenia. $\mathrm{W}$ minionym roku szkolnym 11 uczniów było objętych nauczaniem indywidualnym, z kolei 19 miało orzeczenie o potrzebie kształcenia specjalnego. Warto podkreślić, że osiąganie sukcesów szkolnych dzieci utrudniają m.in. obniżona sprawność intelektualna, zaburzenia i deficyty rozwojowe, zakłócenia $\mathrm{w}$ rozwoju motywacji i postaw. W związku z powyższym, w szkole zatrudnieni są: pedagog szkolny, psycholog, pielęgniarka, logopeda, nauczyciele specjaliści z zakresu terapii pedagogicznej, oligofrenopedagogiki, tyflopedagogiki, surdopedagogiki, neurologopedii, terapii Biofeedback, psychokorekcji zaburzeń zachowania oraz zaburzeń ze spektrum autyzmu.

- Ośrodek Brothers of Chairity Services w Chorley (Wielka Brytania) placówka przeznaczona jest dla osób z niepełnosprawnością intelektualną w stopniu umiarkowanym i głębokim. Działa pod patronatem charytatywnej organizacji Brothers of Chairity, która została założona w 1807 roku przez belgijskiego księdza Petera Triesta i pierwotnie była prowadzona przez zakon-

\footnotetext{
${ }^{15}$ https://klassikka.onedu.fi/web/international/ [dostęp: 24.04.2017].
} 
ników. Obecnie organizacja prowadzi swoją działalność w Belgii, Kanadzie, USA, Szkocji, Anglii, Irlandii, Holandii, RPA, Rwandzie, Burundi, Indonezji, Japonii, Peru, Papui Nowej Gwinei, Zairze i na Filipinach. W Wielkiej Brytanii jest to jedna z największych prywatnych organizacji zajmujących się osobami niepełnosprawnymi intelektualnie. Zatrudnia około 1000 osób, a pod swoją opieką ma około 500 podopiecznych. Mieszkają oni w kilkuosobowych domach lub jednoosobowych mieszkaniach. Każdy dom/mieszkanie ma przydzielony wykwalifikowany personel, którego zadaniem jest wspieranie podopiecznych w ich codziennym życiu ${ }^{16}$.

Analizę wykorzystania technologii ICT w wymienionych instytucjach wyznaczają postawione pytania badawcze:

1. Jak nowoczesne technologie informacyjne są wykorzystywane przez badane instytucje w podejmowanych działaniach edukacyjnych?

2. Jak nowoczesne technologie informacyjne są wykorzystywane przez badane instytucje w podejmowanych działaniach profilaktycznych?

3. Jak nowoczesne technologie informacyjne są wykorzystywane przez badane instytucje $\mathrm{w}$ podejmowanych działaniach terapeutycznych/kompensacyjnych?

W celu odpowiedzi na postawione pytania zastosowano metodę monografii instytucji ${ }^{17}$, a wykorzystanymi technikami badawczymi były z kolei: analiza dokumentów ${ }^{18}$ (w tym dokumentów online) oraz wywiad nieskategoryzowany ${ }^{19} \mathrm{z}$ pracownikami wymienionych instytucji to jest dyrektorami placówek (Kuopio, Bytom), pedagogiem szkolnym (Bytom) oraz opiekunem (Chorley).

\section{Wyniki badań własnych}

\section{Wykorzystanie ICT w działaniach edukacyjnych badanych instytucji}

Szybki rozwój technologii informatycznej wnosi nową jakość do edukacji. Przede wszystkim w procesie edukacji warto wykorzystywać dwie charakterystyczne cechy mediów cyfrowych: interaktywność i integrację ${ }^{20}$. Interaktywność umożliwia aktywniejsze i bardziej samodzielne zdobywa-

${ }^{16}$ A. Kęsiak, Wspieranie potencjału zdrowotnego osób z upośledzeniem umystowym w organizacji Brothers of Charity Services w Wielkiej Brytanii, [w:] Psychospoteczne i środowiskowe konteksty zdrowia $i$ choroby, red. K. Borzucka-Sitkiewicz, Katowice 2016, s. 193-206.

17 A.W. Maszke, Metody i techniki badań pedagogicznych, Rzeszów 2008, s. 160.

18 Tamże, s. 257-158.

19 Tamże, s. 223.

${ }^{20}$ J. van Dijk, Społeczne aspekty nowych mediów. Analiza społeczeństwa sieci, przekł. J. Konieczny, Warszawa 2010. Podano za: A. Rygałło, Czy szkoła może być cyfrowa? [w:] Człowiek, technologia, media, s. 30 . 
nie wiedzy, natomiast integracja wpływa na percepcję i poznanie uczniów. W konsekwencji można zaobserwować przejście do całkiem odmiennej aktywności intelektualnej, przejście od uczenia się linearnego do uczenia przez skojarzenia ${ }^{21}$. Ponadto, jak wskazuje Joanna Juszczyk-Rygałło, wykorzystywanie multimediów w edukacji wczesnoszkolnej przyczynia się w znacznym stopniu do ułatwienia łączenia nauki z zabawą, zwiększenia motywacji do nauki oraz umożliwienia indywidualizacji procesu kształcenia ${ }^{22}$.

Powyższe procesy, ze względu na przedział wiekowy, w którym znajdują się uczniowie, można zaobserwować przede wszystkim w szkole podstawowej z Bytomia. Zgodnie z opinią pedagoga szkolnego, uczniowie chętniej angażują się w zajęcia wspomagane technologią komputerową, ponieważ są one dla nich ciekawsze. Wspomaganie to jest związane przede wszystkim z wykorzystaniem tablic multimedialnych do prowadzenia zajęć lekcyjnych. Dodatkowo nauczanie i wychowanie uczniów jest wspierane przez multimedialne programy edukacyjne, to jest Verim 3.0, Porusz Umysł czy Akademia Umystu wykorzystywane podczas indywidualnych spotkań z pedagogiem. Ponadto, w bibliotece szkoły funkcjonuje tak zwane Centrum Multimedialne, wyposażone w kilka komputerów z dostępem do Internetu, w którym uczniowie mogą poszukiwać informacji potrzebnych im do zajęć lekcyjnych.

W szkole w Kuopio zastosowanie nowoczesnych technologii do wspierania aktywności edukacyjnej jest traktowane jako działanie priorytetowe, a korzystanie z materiałów dostępnych online stanowi nieodłączną część procesu nauczania. Uczniowie w trakcie różnorodnych zajęć analizują zamieszczone w Sieci filmy, fotografie, blogi, klipy i artykuły, żeby je komentować, analizować i w twórczy sposób wykorzystywać. Udostępniają sobie też analizowane materiały z użyciem mediów społecznościowych, a aktywność ta jest kierowana i nadzorowana przez nauczyciela, który wcześniej selekcjonuje odpowiednie materiały, a często także na ich podstawie przygotowuje określone zestawy zadań do wykonania dla uczniów. Z myślą o uczniach tworzone są również edukacyjne i instruktażowe aplikacje na smartfony, które nie tylko wspomagają proces nauczania, ale także pomagają w treningu sportowym, na przykład poprzez monitorowanie planu treningowego czy prezentację prawidłowego sposobu wykonywania ćwiczeń. Lekcje odbywające się w szkole są rejestrowane, aby nieobecni uczniowie mogli je odtworzyć w domu i na tej podstawie wykonać powierzone im zadania - zabieg ten jest szczególnie przydatny w oddziałach sportowych, których wychowankowie często opuszczają zajęcia szkolne ze względu na wymagający cykl treningowy. Ponadto, każdy uczeń samodzielnie układa własny plan lekcji na każdy kolejny semestr z użyciem szkolnego programu komputerowego dostępnego online.

\footnotetext{
${ }^{21}$ A. Rygałło, Czy szkoła może być cyfrowa? s. 31.

${ }^{22}$ J. Juszczyk-Rygałło: Nowe media a kształt wczesnej edukacji, [w:] Człowiek, technologia, media, s. 59 .
} 
Przy układaniu harmonogramu konieczne jest przestrzeganie następujących zasad: dopuszczalna liczba lekcji w ciągu dnia to 5 (1 lekcja trwa 75 minut, a każda przerwa 15 minut z wyjątkiem jednej dłuższej przerwy na lunch), lekcje najwcześniej można rozpoczynać o 8.10, a kończyć - najpóźniej o 15.50. Na korytarzach szkoły zlokalizowane są stanowiska komputerowe z dostępem do Internetu, z których uczniowie mogą korzystać podczas przerw. W szkole dostępne są też drukarki komputerowe, w tym drukarka 3D, z których każdy uczeń może dowolnie korzystać, pod warunkiem że wpłaci na ten cel 10 euro w każdym kolejnym roku szkolnym. Od połowy lat 90. XX wieku szkoła współpracuje z University of Eastern (w Finlandii), realizując wspólnie z nim kolejne projekty edukacyjno-badawcze. Ostatni projekt, przewidziany na lata 2016-2017 i realizowany we współpracy z Wydziałem Fizyki, zakłada stworzenie laboratorium wirtualnej rzeczywistości. W ramach projektu realizowane są lekcje fizyki i chemii, w trakcie których uczniowie testują i pomagają w tworzeniu okularów 3D. Dzięki nim możliwe będzie oglądanie trójwymiarowych obrazów i poruszanie się w wirtualnej rzeczywistości. Docelowo okulary te mają służyć jako pomoc w prowadzeniu lekcji fizyki, chemii, biologii i historii.

\section{Wykorzystanie ICT w działaniach profilaktycznych badanych instytucji}

Zgodnie z definicją Krzysztofa Ostaszewskiego, profilaktyka to „świadome działanie mające na celu zapobieganie problemom (zaburzeniom, chorobom, dysfunkcjom), zanim one wystąpią", co oznacza, że działania profilaktyczne mają przede wszystkim charakter uprzedzający, a nie naprawczy. Odróżniają się zatem wyraźnie od działań terapeutycznych, podejmowanych dopiero w chwili, kiedy pojawi się choroba lub dysfunkcja. Niezbędnym warunkiem do podjęcia oddziaływań profilaktycznych jest posiadanie wiedzy na temat czynników ryzyka danego zaburzenia, rozumianych jako zbiór/ wypadkowa właściwości indywidualnych (tj. zachowania, postawy, przekonania, predyspozycji i uwarunkowań biologicznych) oraz środowiskowych, które wiążą się ze zwiększonym prawdopodobieństwem jego wystąpienia. Po identyfikacji tych czynników możliwe jest minimalizowanie ich szkodliwego działania poprzez wdrażanie odpowiednich strategii profilaktycznych ${ }^{23}$.

Ostatnio zaczyna dominować pogląd, że profilaktyka nastawiona jedynie na ograniczanie niekorzystnych czynników i zjawisk ma charakter defen-

${ }^{23}$ K. Ostaszewski, Edukacja zdrowotna w profilaktyce chorób i zachowań ryzykownych dla zdrowia, [w:] Edukacja zdrowotna. Podstawy teoretyczne. Metodyka. Praktyka, red. B. Woynarowska, Warszawa 2017, s. 114. 
sywny, czy wręcz negatywny, z uwagi na fakt, że koncentruje się głównie na zagrożeniach. W konsekwencji coraz większą popularność zaczyna zdobywać tak zwana profilaktyka pozytywna, opierająca się na innym mechanizmie kontroli czynników ryzyka niż ich ograniczanie czy usuwanie. W tym paradygmacie kładzie się nacisk na równoważenie/kompensowanie siły czynników ryzyka poprzez rozwijanie i wzmacnianie zasobów indywidualnych i środowiskowych, czyli tak zwanych czynników chroniących. Podejście pozytywne koncentruje się na wzmocnieniu tych aspektów funkcjonowania jednostki, które sprawiają, że jest ona bardziej odporna na zagrożenia i stanowią swego rodzaju przeciwwagę dla stresorów, czynników ryzyka, sytuacji kryzysowych, wyzwań oraz trudności napotykanych w ciągu życia ${ }^{24}$.

Niezwykle ważnym aspektem wykorzystywania technologii ICT $\mathrm{w}$ tak pojmowanej profilaktyce jest modelowanie zachowań pożądanych społecznie u różnych grup wiekowych. Służą temu programy przeznaczone dla osób z deficytami w zakresie umiejętności nawiązywania, kształtowania i rozwijania prawidłowych relacji międzyludzkich, w tym procesów komunikacyjnych (są to m.in. osoby objęte programami resocjalizacyjnymi i wychowawczymi $)^{25}$. W szkole w Bytomiu przykładem tego typu działań jest zapobieganie rozwojowi dysfunkcji psychospołecznych oraz wykluczeniu cyfrowemu w trakcie zajęć organizowanych w świetlicy socjoterapeutycznej, podczas których wychowankowie mają stały dostęp do komputerów/Internetu, a także możliwość korzystania z dostępnych programów edukacyjno-terapeutycznych. Ponadto, warto zwrócić uwagę, że dzięki przyjęciu definicji profilaktyki pozytywnej, wszystkie wymienione w poprzednim punkcie działania wspierające aktywność edukacyjną można jednocześnie taktować jako oddziaływania profilaktyczne, wzmacniające czynniki chroniące.

\section{Wykorzystanie ICT \\ w działaniach terapeutycznych/kompensacyjnych badanych instytucji}

Technologie informacyjno-komunikacyjne wykorzystuje się obecnie $\mathrm{w}$ diagnostyce i terapii psychopedagogicznej między innymi do wspomagania rozwoju dzieci i młodzieży z wrodzonymi lub nabytymi deficytami poznawczymi ${ }^{26}$. Służą temu przede wszystkim specjalistyczne programy komputerowe, które stosuje się $\mathrm{w}$ odniesieniu do osób $\mathrm{z}$ różnymi formami i stopniami niepełnosprawności intelektualnej, osób z chorobami narządów

${ }^{24}$ Tamże, s. 115.

25 A. Ogonowska, Wspótczesna edukacja medialna, s. 43.

26 A. Lechowicz, Komputerowe wspomaganie procesu komunikacji niewerbalnej dzieci z wieloraka niepetnosprawnością, Warszawa 2005. Podano za: tamże.. 
zmysłów, zaburzeniami procesów poznawczych, czy z problemami z czytaniem i pisaniem ${ }^{27}$. Warto zauważyć, że technologia jest tu wykorzystywana nie tylko wśród dzieci i młodzieży, ale także osób dorosłych (które np. doznały uszkodzeń neurologicznych na skutek wypadku czy choroby) i w wie$\mathrm{ku}$ senioralnym ${ }^{28}$. Rozwój technologii informacyjnej umożliwia także udział w procesie edukacji osób niepełnosprawnych ruchowo, na przykład poprzez rozwój tak zwanego e-learningu (edukacja na odległość). Osoby te korzystają najczęściej z takich aplikacji, jak: przeglądarki internetowe, poczta elektroniczna, komunikatory, wyszukiwarki, fora dyskusyjne, interaktywne programy. Niepełnosprawni, którzy mają problemy ze wzrokiem czy słuchem mogą korzystać z syntetyzatorów mowy, monitorów brajlowskich, programów czytających dane z ekranu czy programów powiększających ${ }^{29}$. W tym kontekście warto zauważyć, że dzięki kolejnym wynalazkom i innowacjom mającym na celu poprawę jakości funkcjonowania osób niepełnosprawnych, również kształcenie tych osób będzie w przyszłości łatwiejszą i dostępniejszą formą samodoskonalenia i zdobywania kompetencji zawodowych.

Warto zauważyć, że niezwykle istotnym, jeśli nie najważniejszym, celem wykorzystania technologii ICT w oddziaływaniach rehabilitacyjnych i leczniczych jest optymalizacja dobrostanu psychofizycznego człowieka oraz odzyskanie możliwości jak najlepszego funkcjonowania społecznego ${ }^{30}$. Wszystkie te cele są realizowane w Ośrodku w Chorley, w którym podejmowane działania terapeutyczne i kompensacyjne zmierzają nie tylko do poprawy jakości życia podopiecznych, ale także do ich możliwie najpełniejszej integracji społecznej, a technologia ICT ma w tym kontekście szerokie zastosowanie. Każdy z rezydentów - o ile wyrazi takie pragnienie - posiada tablet zapewniający dzięki funkcji dotykowej bezpośredni i łatwy dostęp do różnych aplikacji. Panadto, w każdym domu jest zainstalowany komputer (PC) służący wszystkim domownikom oraz personelowi. Używa się go do bieżącej komunikacji oraz organizacji zajęć dla rezydentów. W wypadku osób, które nie potrafią czytać, komputer oraz tablet używane są do wyświetlania grafiki i zdjęć, aby w ten sposób pomóc im zrozumieć, o jakie zajęcia chodzi. Spora grupa rezydentów korzysta ze Skype'a w kontaktach ze swoją rodziną lub przyjaciółmi. Nawet jeśli jakaś osoba sama nie potrafi go uruchomić, korzysta z niego mimo wszystko przy pomocy personelu. Komputer i tablet służą też

${ }_{27}$ Zob. J. Gruba, Multimedialny Pakiet Logopedyczny, [w:] Kompetencje medialne społeczeństwa wiedzy, red. W. Strykowski, W. Skrzydlewski, Poznań 2004.

28 A. Ogonowska, Wspótczesna edukacja medialna, s. 42.

${ }_{29}$ Cz. Ślusarczyk, Rola Internetu w edukacji osób niepetnosprawnych, [w:] E-edukacja.net. Materiały z III ogólnopolskiej konferencji: „Rozwój e-edukacji w ekonomicznym szkolnictwie wyższym", red. M. Dąbrowski, M. Zając, Warszawa 2007. Podano za: tamże.

${ }^{30}$ A. Ogonowska, Współczesna edukacja medialna, s. 42. 
do dokonywania zakupów online dla rezydentów - w ten sposób zamawia się bilety do kina, teatru lub na koncerty. Dla rezydentów, którzy chodzą do college'u część materiałów edukacyjnych dostępna jest online tak, że mogą usprawniać na przykład pisanie lub czytanie korzystając z serwisu internetowego danej placówki.

W warunkach polskich korzystanie z technologii ICT jest nieco bardziej ograniczone. Nie wykorzystuje się jej do tak szerokiej integracji społecznej, jak ma to miejsce w ośrodku brytyjskim, niemniej ma ona zastosowanie przy wspomaganiu konkretnych działań terapeutycznych. W bytomskiej szkole zwraca uwagę przede wszystkim organizacja zajęć rewalidacyjnych i korekcyjno-kompensacyjnych w tak zwanej Sali Doświadczania Świata, wyposażonej w szereg pomocy stymulujących rozwój psychofizyczny wspomaganych technologią komputerową. Należy do nich przede wszystkim tak zwany Magiczny Dywan, na którym, dzięki obrazowi wyświetlanemu przez projektor multimedialny, mogą być organizowane aktywności rozwijające/usprawniające funkcje motoryczne i/lub psychospołeczne u podopiecznych. W sali tej odbywają się zajęcia dla uczniów z takimi deficytami rozwojowymi, jak: ADHD, zaburzenia zachowania, niepełnosprawność intelektualna, motoryczna, słuchowa i wzrokowa, autyzm czy dysharmonie rozwojowe. Dodatkowo, w korygowaniu problemów ogólnorozwojowych, poznawczych i społeczno-emocjonalnych wykorzystywana jest specjalistyczna aparatura do terapii Biofeedback, używana przez odpowiednio przeszkolonych $\mathrm{w}$ tym kierunku nauczycieli. Wreszcie, zajęcia logopedyczne, często organizowane dla uczniów z innymi sprzężonymi deficytami, są także wspomagane technologią komputerową.

\section{Podsumowanie}

Jak dowodzą coraz liczniej powstające raporty odnośnie wykorzystywania nowoczesnych technologii $\mathrm{w}$ procesie edukacji, polscy nauczyciele mają do nich stosunek ambiwalentny. Przeprowadzone na próbie 800 nauczycieli badania Nowe media w polskiej szkole ${ }^{31}$ wskazują, że nauczyciele dość chętnie wyszukują w Sieci materiały dydaktyczne - codziennie robi to $40,4 \% \mathrm{z}$ nich, a jednocześnie są niezbyt skłonni do przesyłania uczniom przez Internet materiałów dydaktycznych - nigdy nie zrobiło tego aż 46,9\% osób. Z kolei, powstały raport oparty na badaniach Edunews.pl ${ }^{32}(\mathrm{~N}=189)$ wykazał, że

${ }^{31}$ D. Batorski, J. Jasiewicz i in., Nowe media w polskiej szkole, http://regionalneobserwatoriumkultury.pl/tl_files/olek/Nowe\%20media\%20w\%20polskiej\%20szkole\%20-\%20wyniki\%20bada.pdf [dostęp: 25.07.2017].

32 Jaknowe technologie pomagają uczyć? Wyniki badań Edunews.pl wśród nauczycieli polskich szkót. http://www.edunews.pl/images/pdf/jak_nowe_tech_pomagaja.pdf [dostęp: 25.07.2017]. 
połowa ankietowanych nauczycieli uznaje brak czasu za główną przeszkodę w korzystaniu z nowych technologii. Można to rozumieć co najmniej na dwa sposoby: po pierwsze, przygotowanie lekcji z użyciem technologii informacyjnych jest bardziej czasochłonne niż prowadzonych metodą tradycyjną, a po drugie - z wykorzystaniem tych technologii są bardziej czasochłonne same w sobie, ponieważ wymagają podłączenia sprzętu w klasie lub przejścia do pracowni komputerowej, zorganizowania pracy przy komputerach itp. Ponadto, prawie $40 \%$ ankietowanych uważa, że braki w wyposażeniu szkoły są dla nich przeszkodą w wykorzystaniu nowych mediów.

Tymczasem, jak wykazano powyżej, wykorzystanie nowoczesnych technologii $w$ procesie wychowania i nauczania może być niezwykle cenne. Pozwalają one bowiem pozyskiwać i tworzyć informacje w nielinearny sposób, co sprawia, że mogą stać się ważnym narzędziem edukacji i kompensacji, które będzie nie tylko wspomagać przekaz edukacyjny, lecz także go kształtować. Wymiana informacji może przy tym obejmować tekst, obraz, animację, film, czy dźwięk, publikowane w sposób hipertekstowy, co daje użytkownikowi ogromną swobodę w przyswajaniu nowych wiadomości i umiejętności. Ten brak ograniczeń i struktury stanowi zarówno wyzwanie, jak i szansę $\mathrm{w}$ procesach edukacyjno-kompensacyjnych ${ }^{33}$.

Przeprowadzone badania dowiodły, że nowoczesne technologie mogą być wykorzystywane wielokierunkowo. Przede wszystkim, stwarzają szansę na usprawnienie i uatrakcyjnienie procesu edukacji, ze względu na fakt, że wzbogacają tradycyjne formy przekazywania wiedzy, pozwalają na dwukierunkową komunikację, a także umożliwiają komunikowanie się oddalonych od siebie uczestników procesu dydaktycznego (w czasie rzeczywistym i odroczonym), przez co ułatwiają zdobywanie wykształcenia osobom, które napotykają na swojej ścieżce edukacyjnej przeszkody natury organizacyjnej czy funkcjonalnej (deficyty rozwojowe, niepełnosprawność itp.). Ponadto, cyfrowe media mogą być wykorzystywane na wszystkich poziomach profilaktyki, w stosunku do różnych grup społecznych, ze względu na skuteczne wspomaganie procesów readaptacyjnych i kompensacyjnych przy jednoczesnym zapobieganiu wykluczeniu cyfrowemu, co stanowi nadrzędny cel tak zwanej edukacji włączającej ${ }^{34}$. Także, praktyki stosowane w warunkach fińskich czy brytyjskich wskazują, że do działań edukacyjnych i readaptacyjnych można wprowadzić wiele nowych elementów związanych z technologią cyfro-

${ }^{33}$ M. Cylkowska-Nowak, E. Wierzejska, Technologie informacyjne w edukacji zdrowotnej, [w:] Edukacja zdrowotna. Podstawy teoretyczne. Metodyka. Praktyka, red. B. Woynarowska, Warszawa 2017, s. 204.

${ }^{34}$ A. Watkins, Technologie informacyjne i komunikacyjne w edukacji właczającej. Rozwój dziedziny i nowe możliwości w państwach europejskich, http:/ / www.europeanagency.org/publications/ ereports [dostęp: 25.07.2017]. 
wą, przy umiejętnym/innowacyjnym wykorzystaniu narzędzi, które są już ogólnie dostępne w większości placówek. Warto zatem koncentrować się nie tylko na zagrożeniach płynących ze współczesnej wszechobecności nowych mediów, ale także na szansach jakie stwarzają, mając na uwadze fakt, że przy braku możliwości całkowitego ograniczenia ich wpływu, ważne jest, by wykorzystywać je w konstruktywny sposób.

\section{BIBLIOGRAFIA}

Batorski D., Jasiewicz J. i in., Nowe media w polskiej szkole, http://regionalneobserwatoriumkultury.pl/tl_files/olek/Nowe\%20media \%20w\%20polskiej\%20szkole \%20-\%20 wyniki\%20bada.pdf [dostęp: 25.07.2017].

Cylkowska-Nowak M., Wierzejska E., Technologie informacyjne w edukacji zdrowotnej, [w:] Edukacja zdrowotna. Podstawy teoretyczne. Metodyka. Praktyka, red. B. Woynarowska, PWN, Warszawa 2017.

Gruba J., Multimedialny Pakiet Logopedyczny, [w:] Kompetencje medialne społeczeństwa wiedzy, red. W. Strykowski, W. Skrzydlewski, Wydawnictwo: eMPi2, Poznań 2004.

http:/ / ec.europa.eu/information_society/events/ict_riga_2006/doc_declaration_riga. pdf. [dostęp: 28.02.2012].

http:// www.nauka.gov.pl/g2/oryginal/2013_05/5de4e12caa5c43f9e7ad159505c26e03. pdf [dostęp: 12.07.2017].

http://www.umwd.dolnyslask.pl/fileadmin/user_upload/spoleczenstwo_informacyjne/dokumenty/Strategia_Rozwoju_Spoleczenstwa_Informacyjnego_w_Polsce.pdf [dostęp: 12.07.2017].

https://klassikka.onedu.fi/web/international/ [dostęp: 24.04.2017].

https:// mc.gov.pl/projekty/ogolnopolska-siec-edukacyjna [dostęp: 12.07.2017].

https://mc.gov.pl/projekty/ogolnopolska-siec-edukacyjna/opis-projektu [dostęp:12.07.2017].

Jak nowe technologie pomagaja uczyć? Wyniki badań Edunews.pl wśród nauczycieli polskich szkót. http://www.edunews.pl/images/pdf/jak_nowe_tech_pomagaja.pdf [dostęp: 25.07.2017].

Juszczyk-Rygałło J.: Nowe media a kształt wczesnej edukacji, [w:] Człowiek, technologia, media. Konteksty kulturowe i psychologiczne, red. A. Ogonowska, G. Ptaszek, Oficyna Wydawnicza Impuls, Kraków 2014.

Kęsiak A., Wspieranie potencjału zdrowotnego osób z upośledzeniem umysłowym w organizacji Brothers of Charity Services w Wielkiej Brytanii, [w:] Psychospołeczne i środowiskowe konteksty zdrowia i choroby, red. K. Borzucka-Sitkiewicz, Wydawnictwo Uniwersytetu Śląskiego, Katowice 2016.

Kłak M., Zarzadzanie wiedza we wspótczesnym przedsiębiorstwie, Wydawnictwo Wyższej Szkoły Ekonomii i Prawa im. Prof. Edwarda Lipińskiego w Kielcach, Kielce 2010.

Komunikat Komisji do Parlamentu Europejskiego, Rady, Europejskiego Komitetu Ekonomiczno-Społecznego i Komitetu Regionów, Europejska inicjatywa i2010 na rzecz e-integracji: „Uczestnictwo w społeczeństwie informacyjnym” [SEK (2007) 1469] [SEK (2007) 1470], Bruksela 8.11.2007, KOM (2007) 694.

Lechowicz A., Komputerowe wspomaganie procesu komunikacji niewerbalnej dzieci z wieloraka niepetnosprawnościa, WSiP, Warszawa 2005.

Manovich L., Język nowych mediów, Wydawnictwa Akademickie i Profesjonalne, Warszawa 2006. 
Maszke A.W., Metody i techniki badań pedagogicznych, Wydawnictwo Uniwersytetu Rzeszowskiego, Rzeszów 2008.

Ogonowska A., Wspótczesna edukacja medialna: teoria i rzeczywistość, Wydawnictwo Naukowe Uniwersytetu Pedagogicznego w Krakowie, Kraków 2013.

Ostaszewski K., Edukacja zdrowotna w profilaktyce chorób i zachowań ryzykownych dla zdrowia, [w:] Edukacja zdrowotna. Podstawy teoretyczne. Metodyka. Praktyka, red. B. Woynarowska, Wydawnictwo Naukowe PWN, Warszawa 2017.

Rygałło A., Czy szkoła może być cyfrowa? [w:] Człowiek, technologia, media: konteksty kulturowe i psychologiczne, red. A. Ogonowska, G. Ptaszek, Oficyna Wydawnicza Impuls, Kraków 2014.

Szczeszek K., Technologie informacyjne a edukacja, [w:] Oblicza Internetu, red. M. Sokołowski, Państwowa Wyższa Szkoła Zawodowa w Elblągu, Elbląg 2004.

Ślusarczyk Cz., Rola Internetu w edukacji osób niepełnosprawnych, [w:] E-edukacja.net. „Materiały z III ogólnopolskiej konferencji Rozwój e-edukacji w ekonomicznym szkolnictwie wyższym", red. M. Dąbrowski, M. Zając, Warszawa 2007.

van Dijk J., Społeczne aspekty nowych mediów. Analiza społeczeństwa sieci, przekł. J. Konieczny, Wydawnictwo Naukowe PWN, Warszawa 2010.

Watkins A., Technologie informacyjne i komunikacyjne w edukacji właczającej. Rozwój dziedziny i nowe możliwości w państwach europejskich, http:/ / www.europeanagency.org/ publications/ereports [dostęp: 25.07.2017] 